\title{
Assessment of tillage erosion by mouldboard plough in Tuscany (Italy)
}

\author{
S. De Alba , L. Borselli , D. Torri ', S. Pellegrini , P. Bazzoffi
}

\begin{abstract}
This study was designed to characterise the soil translocation effect induced by mouldboard ploughing with an implement traditionally used in the Tuscany region (Central Italy). We discuss the results of a set of field experiments performed to measure soil displacement along slopes of varying gradient in different directions and at several depths of tillage. Using the Soil Erosion by Tillage (SETi) model, soil translocation patterns for different tillage scenarios were analysed, with special attention paid to the effects of the direction and depth of tillage on the extent and spatial pattern of soil movement. The lateral slope gradient $S_{\mathrm{P}}$ and tillage depth $D$ were found to be the dominant controlling factors for total soil displacement. The effect of the slope gradient in a direction parallel to tillage $S_{\mathrm{T}}$ was much less pronounced. These findings reveal the importance of the asymmetric nature of the soil movement produced by mouldboard ploughing and the predominant effect of the lateral displacement $d_{\mathrm{P}}$ on the actual trajectory of soil motion. Results demonstrate that spatial patterns of soil redistribution due to mouldboard ploughing are highly variable and depend on the particular characteristics of the implement used. This dependence is so strong that maximum downslope soil translocation can occur during both, contour tillage or up-down tillage. For this particular mouldboard plough, maximum downslope soil transport took place at a tillage direction ca. $70^{\circ}$ and not when tillage was conducted along the steepest slope direction $\left(0^{\circ}\right)$. These findings highlight the potential of the combined approach applied. The physically based SETi model can be properly calibrated using a relatively limited dataset from field experiments. Once calibrating, the SETi model can then be used to generate synthetic tillage translocation relationships, which can predict the intensity and spatial pattern of soil translocation over a much wider range of tillage scenarios than the particular experimental conditions, in terms of topography complexity (slope gradients and morphology) and the direction and depth of tillage. These synthetic relationships are useful tools for evaluating strategies designed to reduce tillage erosion.
\end{abstract}

Keywords: Tillage erosion; Tillage translocation; SETi model; Field experiments; Modelling; Metal tracers; Electromagnetic probe 


\section{Introduction}

Tillage has been recognised as a cause of intense landscape modification and as a majør søurce of søil erosion and redistribution along hillslopes (Guiresse and Revel, 1995; Govers et al., 1999; Torri et al., 2002). The first documented experimental study in which soil translocation by tillage was evaluated dates back to the 1940's (Mech and Free, 1942). Despite profound evidence of soil translocation processes, it was only in the 1990s that systematic research on this tøpic began (e.g., Lindstrom et al., 1990, 1992; Gøvers et al., 1994; Quine et al., 1994; Løbb et al., 1995).

The practice of mouldboard pløughing warrants particular attention, since it is the most common methød of primary tillage used in conventional agriculture systems. Further, it has been reported that

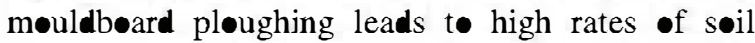
transport and erosion (e.g., Govers et al., 1994; Gerontidis et al., 2001). The mouldboard plough causes the detachment and movement of the entire tops layer (i.e., the plough layer), generally at a

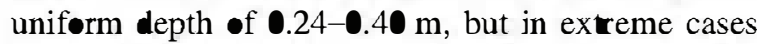
such as those of cropped areas of clayey søils in the Tuscany region, tillage depth frequently surpasses $0.50 \mathrm{~m}$. Of particular interest are the experimental works related the use of the mouldb ard pløugh by Lindstrom et al. (1990, 1992), Revel et al. (1993), Gøvers et al. (1994), Løbb et al. (1995, 1999), De Alba (1998, 2001), Van Muysen et al. (1999, 2002), Torri and Borselli (2002) and Gerøntidis et al. (2001).

The morpholøgy (slope gradient, curvature) and characteristics of tillage operations (tillage implement, and the direction, speed and depth of tillage) appear to be the main factors controlling soil redistribution over a slope. Soil displacement is proportional to the gradient of the løcal sløpe, while net rates of soil loss or gain are related to the morphøløgy and curvature of the slope, i.e., that erosion prevails on convexities or shoulders and deposition prevails in concavities or hollows (e.g., Lindstrom et al., 1992; Govers et al., 1999). In an independent manner, De Alba (2001) and Torri and Borselli (2002) recently demonstrated that soil displacement due to mouldboard ploughing is not only affected by the local steepest slope gradient but als by the relative orientation of the slope aspect with respect to the tractor's direction of motion. These authors argue that to accurately describe søil transløcation, the actual rajectory of soil movement needs to be determined along with the total displacement distance. Soil displacement along the steepest slope direction is only one component of the søil motion trajectory, and in most cases it is not the dominant direction.

Tillage experiments are the most basic source of data for establishing relatiønships between søil displacement due to tillage and control factors such as the type of implement, the slope gradient, the depth and speed of tillage, etc. However, variables that can be inferred from experimental data are constrained by the limited experimental conditions under which they were $\bullet$ btained; this restriction being greater, the smaller the experimental dataset. For the combined approach used in this paper, experimental data were used to calibrate the physically based Soil Erosion by Tillage (SETi) model, t॰ generate more general søil translocation equations. These equations could then be used to describe the results and extrapølate them to a broader range of tillage scenarios than those of the experimental conditions.

The general •bjective of the present study was to characterise the translocation effects of mouldbøard ploughing using a type $\bullet$ instrument $\bullet$ widespread use in Tuscany (Central Italy). The results $\bullet$ a set $\bullet$ field experiments, performed to measure søil displacement along different slope gradients in different directions and at different depths of tillage, are discussed. Soil translocation patterns in different tillage scenarios were analysed using the SETi model, with special emphasis placed on the effect of the direction and depth of tillage on the extent and spatial pattern $\bullet$ f søil møvement. Finally, we discuss søme of the practical implications of the experimental and theoretical findings in evaluating possible tillage patterns that might reduce tillage erosion.

\section{Methods}

The study area was located at the S. Elisabetta Experimental Centre, Vicarell• (Volterra) in the central hilly region of Tuscany $\left(43^{\bullet} 27^{\prime} \mathrm{N}, 11^{\bullet} 3 \mathbf{0}^{\prime} \mathrm{E}\right.$, $151.5 \mathrm{~m}$ above mean sea level). Its climate is Mediterranean, sub-humid with a mean annual precipitation of $678 \mathrm{~mm}(1954-1996)$. The søil of 
the experimental site is a Vertic Xerorthent (Søil Survey Staff, 1975), developed over Pliøcene clayey marine deposits. The tops il has an average clay cœntent $\bullet 45 \%$, a bulk density of $1.4-1.5 \mathrm{Mg} \mathrm{m}^{-3}$ and an organic carbøn content of $1 \%$. Agrøn॰mical management $\bullet$ this experimental site is that typical to the central Tuscany area. The dominant cropping system is cereal and forage rotation. Cereal cultivation is usually alternated with the growth of forage species, mainly alfalfa, every tw॰ years. Character-

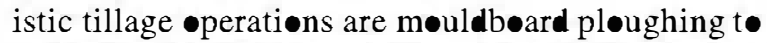
a depth $\bullet$ o. 0 - $0.5 \mathrm{~m}$, føllowed by disking before cereal or alfalfa sowing. The area has a rolling

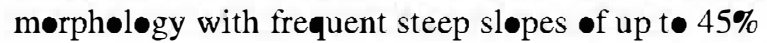
gradient; fields of up t॰ $40 \%$ sløpe being commønly pløughed. In these extreme conditions, it is commøn practice tø conduct tillage aløng a direction $\bullet$ blique to the maximum slope direction. Interviews with local farmers revealed that this tillage pattern is widespread and based on empirical observations.

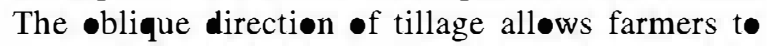
reduce the time of tillage operations, reduce fuel consumption and achieve maximum movement of søil clods and søil loosening.

\subsection{Field experiments designed to quantify soil translocation due to tillage}

Søil displacement due to mouldbøard pløughing was determined in 19 field experiments. The tillage equipment used was similar to the most widespread in the study area. Tillage operations were conducted using a racked tractor with a mouldboard pløugh with a single deep-tillage bottom $45 \mathrm{~cm}$ width. In the experimental hillslope, a detailed survey was performed to løate each plot and determinate its løcal sløpe gradient and aspect. The experimental pløt had an area $\bullet \mathrm{ca} .10 \mathrm{~m}^{2}$, in which an average number $\bullet$ 152 metallic tracers were installed buried in the soil. The tracers were placed along eight microwells, $45 \mathrm{~cm}$ depth and $2 \mathrm{~cm}$ of diameter, at a vertical distance of $2.5 \mathrm{~cm}$ from each $\bullet$ ther. The space between tracers was filled with mud such that they became incorprated int the soil mass. Each tracer was identified by an alphanumeric code. The position of each microwell and tracer was recorded with reference to a local system of Cartesian coordinates $(x, y, z)$ using a Tøtal Station.
For each tillage experiment, we defined the tractor trajectory for the tillage operation and measured the corresponding counter-clockwise angle $(\omega)$ between the slope aspect and the tillage direction. Before each experiment, tillage depth was established outside the experimental plot. During tillage, the speed of the tract was kept constant at an average of between 1.1 and $1.3 \mathrm{~m} \mathrm{~s}^{-1}$. Tillage speed was measured by

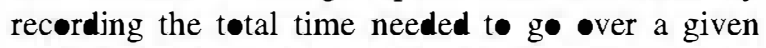
control distance within the plot. The starting søil conditions were: mean soil moisture $12 \%$ and mean søil bulk density $1.5 \mathrm{Mg} \mathrm{m}^{-3}$. A median clød diameter -f $0.1 \mathrm{~m}$ was calculated by analysing clod size distribution in the topsil after tillage using a standard sieving methød and arøund $50 \mathrm{~kg} \bullet$ f søil mass. Table 1 describes the conditions for all the experimental pløts including, slope gradient, direction and depth of tillage and the field method used t• measure tracer displacement: (1) the excavation method or (2) the low-induction electrømagnetic probe method (EM38).

Eleven field experiments were conducted using the excavation method (Fig. 1). These experiments invelved recovering the tracers after tillage using a metal detector. The tracers were then dug out and identified. The final position of each racer was recorded according t a løcal cœordinates system. The difference between the initial and final position of each tracer was used to calculate total tracer displacement and the displacement components in the directions $x, y$ and $z$. For the whole set of experiments, the average proportion of racers recovered was always greater than $\mathbf{9 0 \%}$.

The EM38 electromagnetic probe (Geønics Ltd.) was used in a further eight experiments. This method is based on mapping electromagnetic anomalies induced by the metal tracers incorporated int the søil. The EM38 prøbe measures tøps il electrical conductivity by inducing a secondary magnetic field. The experimental protol used is described in detail in Borselli and Torri (2001). The set-up of the plots for the experiments is similar to that described abøve for the excavation methed except that tracer density is double. In each pløt, 304 racers were placed along tw parallel vertical lines of microwells as indicated in Fig. 2. Unlike the former method, the size and direction of movement is given by the difference between the positions of the centre of mass of the entire set, or "cloud", of tracers before and after the 


\begin{tabular}{|c|c|c|c|c|c|c|}
\hline \multirow[t]{2}{*}{ Plot } & \multicolumn{3}{|c|}{ Slope gradients (\%) } & \multirow{2}{*}{$\begin{array}{l}\text { Tillage direction, } \\
\omega\left({ }^{\bullet}\right)\end{array}$} & \multirow{2}{*}{$\begin{array}{l}\text { Depth of } \\
\text { illage }(\mathrm{m})\end{array}$} & \multirow[t]{2}{*}{ Field method } \\
\hline & $S_{\max }$ & $S_{\mathrm{T}}$ & $S_{\mathbf{P}}$ & & & \\
\hline 1 & 4.0 & -3.9 & -1. & 15 & 0.42 & Excavation method \\
\hline 3 & 25.4 & -23.9 & -8.7 & 2 & $\bullet .42$ & Excavation method \\
\hline 4 & 16.7 & -16.6 & -1.5 & 5 & $\bullet .42$ & Excavation method \\
\hline 5 & 13.1 & -12.8 & -2.7 & 12 & $\bullet .27$ & Excavation method \\
\hline 8 & 25.4 & -25. & -4.4 & 10 & 0.27 & Excavation method \\
\hline 9 & 16.7 & -16.4 & -2.9 & 10 & $\bullet 27$ & Excavation method \\
\hline 10 & 13.1 & -13.1 & -1.1 & 5 & 0.42 & Excavation method \\
\hline 11 & 4.6 & -4.6 & 0.4 & 355 & 0.27 & Excavation method \\
\hline 12 & 23. & -19.1 & -12.9 & 34 & $\bullet .27$ & Electromagnetic probe \\
\hline 17 & 20 & -3.5 & -19.7 & 8 & $\bullet .35$ & Electromagnetic probe \\
\hline 18 & 25. & -10.6 & -22.7 & 65 & $\bullet 28$ & Electromagnetic probe \\
\hline 19 & 39.0 & -16.5 & -35.3 & 65 & $\bullet .35$ & Electromagnetic probe \\
\hline
\end{tabular}

$\omega$, Angle (counter clockwise) between wlage direction and slope aspect, $S_{\max }$, maximum slope gradient; $S_{\mathrm{T}}$, slope gradient in the direction of wlage; $S_{\mathbf{P}}$, slope gradient in the direction perpendicular to tillage.

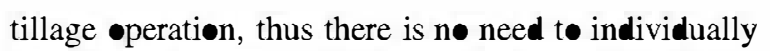
identify each tracer. A rigid wooden frame (Fig. 2) was used as a reference for the local electromagnetic measurements. The main advantage of this method is that it is quick to perform and avoids disturbing the søil surface. The methød is just as accurate, its maximum estimation error being $0.1 \mathrm{~m}$ for the position of the tracer cloud cente of mass (Borselli and Torri, 2001). Initial soil conditions for the experiments were similar to those used for the excavation method.

\subsection{Estimating soil translocation using the Soil Erosion by Tillage model}

The Soil Erosion by Tillage model developed by Torri and Borselli (2002) is a physically based model that simulates the 3D behaviøur of the transported søil.

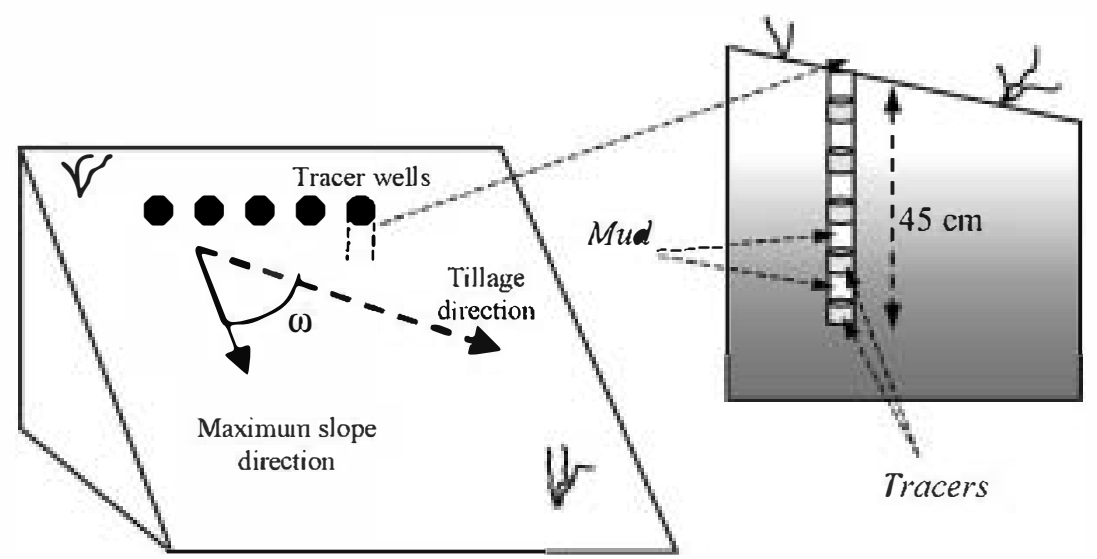

Fig. 1. Site setup of an experimental plot using metal tracers. 


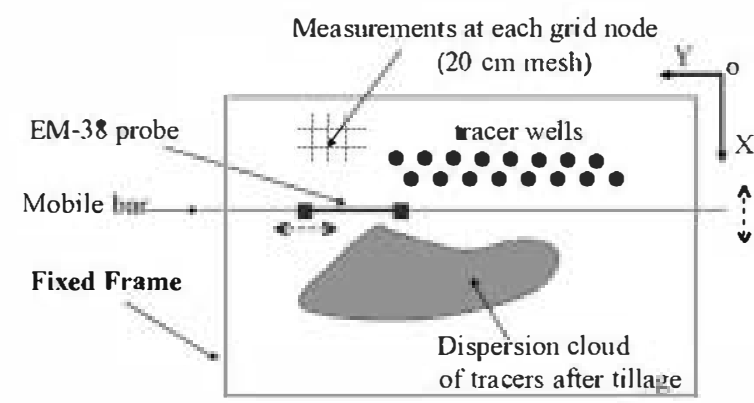

Fig. 2. Experimental setup for measuring the cloud of wacers left after tillage using an EM38 elecromagne probe. The size of the wooden frame use for the Vicarello experiments was $3.5 \mathrm{~m} \times$ $3.5 \mathrm{~m}$.

A flow-chart describing the simulation model is provided in Fig. 3. The model identifies three different phases of søil motion as follows:

(1) Drag phase: movement of soil in contact with the tillage implement. The only significant force is the drag exerted by the tillage device.

(2) Jump phase: søil clods projected by the tillage implement are free to fall under the effects of gravity and of their velocity at the time of ejection.
(3) Rolling phase: the clods roll (or slide) for a while under the effects of gravity, resistance and their velocity immediately after the jump phase (or the drag phase in the absence of jump).

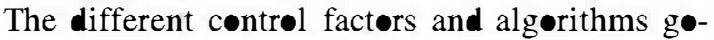
verning each of these motion phases are described in detail in Torri and Borselli (2002). The SETi model is coded int a computer program in a MathLab environment. The input data are the average mass and diameter of the søil cløds, the tillage implement characteristics, the tractor speed and the tillage direction with respect to the slope aspect. The implement characteristics are related to the size and shape of the instrument, and are formulated in terms -f the directions in which the soil is ejected from the møuldbøard blade: the everturning lateral direction $(\boldsymbol{\alpha}$ angle) and the vertical angle of soil ejection ( $\phi$ angle). The outputs of simulation are equations $\boldsymbol{d}$ escribing the soil displacements produced during each motion phase as functions of the maximum sløpe gradient and direction of tillage ( $\omega$ angle) for three different directions of søil møvement: (a) aløng the maximum slope, (b) across the sløpe and (c) in a vertical direction.

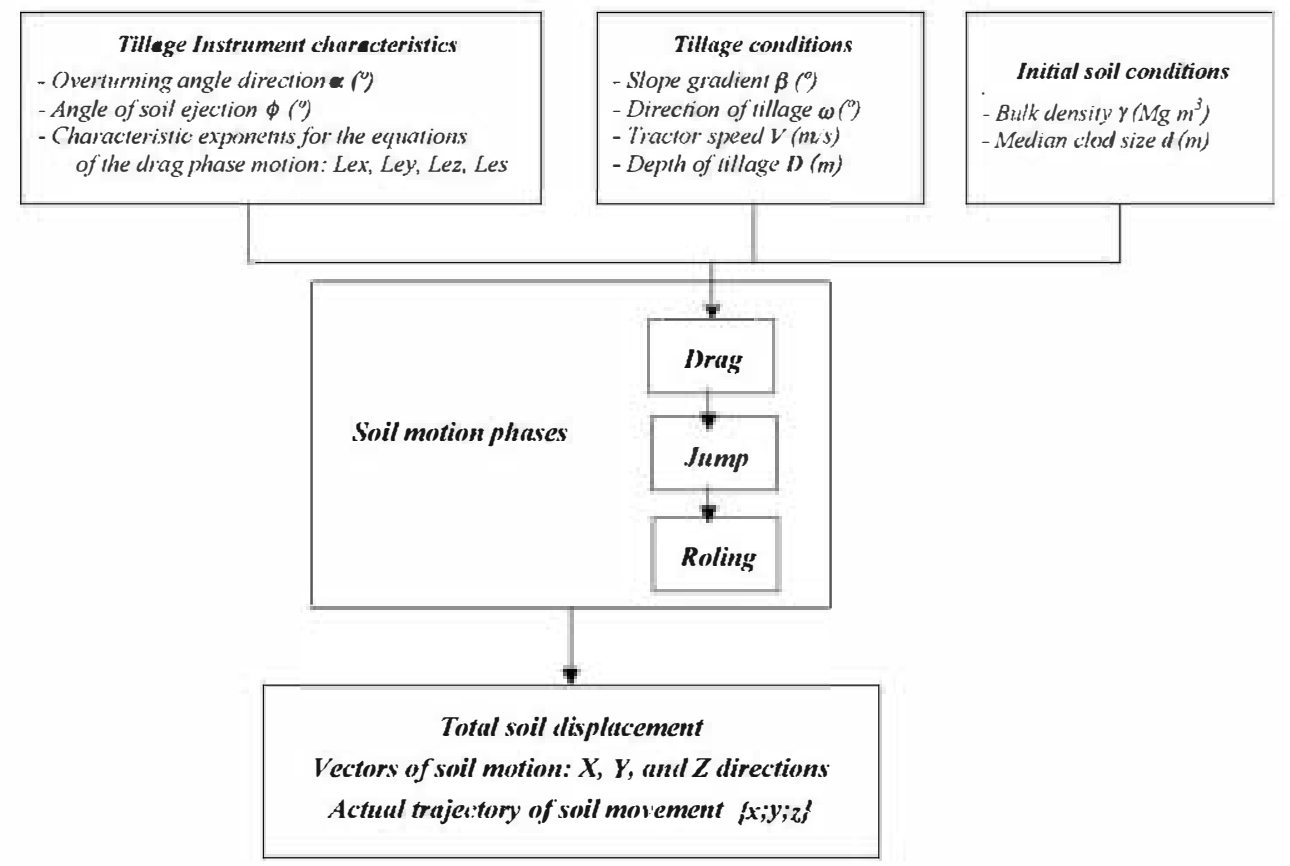

Fig. 3. Flowchart of the Soil Erosion by Tillage (SETi) model 


\section{Results and discussion}

\subsection{Soil displacement versus tillage direction and topography}

There are scarce published experimental data on søil displacement during tillage in a direction oblique to the direction of the steepest slope. The data available are practically only related to tillage conducted up- and downslope or across the slope (contøur tillage). In contrast, our experiments were mainly performed for directions of tillage $\bullet b l i q u e$ t the slope aspect. In most cases, the tillage direction $(\omega)$ was much greater than $5^{\bullet}$; the tillage direction closest to an across-sløpe direction being $\mathbf{8 0}^{\circ}$. Følløwing the convention use by Lindstrom et al. (1990), negative signs were assigned to the slope gradients $S_{\mathrm{T}}$ (sløpe gradient in the direction parallel to tillage) and $S_{\mathrm{P}}$ (slope gradient in the direction perpendicular to tillage) when the ractor moved downslope (i.e., $\left.S_{\mathrm{T}}<0\right)$ or when the søil was overturned laterally downwards (i.e., $S_{\mathrm{P}}<\mathbf{0}$ ), while positive signs were assigned in the opposite cases. Fig. 4 shows a scatter pløt $\bullet$ the sløpe combinations $\bullet S_{\mathrm{T}}$ and $S_{\mathrm{P}}$ used in the field experiments.

The results of the field experiments are outlined in Table 2. We performed a statistical analysis of covariance (ANCOVA) t॰ check for possible differences in the results derived from the two methods of measuring metal racer displacement in the field experiments. In this analysis, the measurement methød was the contrøl factør, tøal søil displacement $d$ was the dependent variable, and $S_{\mathrm{P}}$ and $S_{\mathrm{T}}$ were the

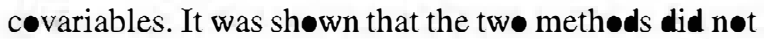
differ significantly $(F(1.15)=0.40, p<0.54)$ and consequently the two experimental datasets were analysed as a single set irrespective of the method used t• estimate søil displacement.

Table 3 shows the correlations between average søil displacements (forward in the direction of tillage $d_{T}$, in a perpendicular direction to that $\bullet$ tillage $\boldsymbol{d}_{\mathrm{P}}$ and along the actual trajectory of soil movement $\boldsymbol{d}$ ) and the slope gradients (in the direction of steepest slope $S_{\max }$ abselute value - parallel to tillage $S_{\mathrm{T}}$ and perpendicular to tillage $S_{\mathrm{P}}$ ). As expected, the regression analysis revealed a weak but significant direct linear relationship between total soil displacement $\boldsymbol{d}$ and the steepest sløpe gradient $S_{\max }\left(r=0.39 ; n=19 ; P_{\text {- }}\right.$ value $<0.05$ ). In contrast, $\boldsymbol{d}$ showed significant inverse correlation with the lateral slope $S_{\mathrm{P}}(r=$ -0.53; $n=19 ; P$-value $<0.05$ ) but no significant association with the forward slope $S_{\mathrm{T}}$. In a parallel similar, $\boldsymbol{d}$ was significantly correlated with the lateral displacement $d_{\mathrm{P}}(r=0.92 ; n=19 ; P$-value $<0.05)$ but not with the forward displacement $\boldsymbol{d}_{\mathrm{T}}$ (Fig. 5).

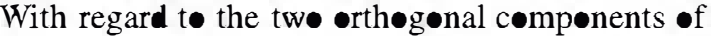
soil movement, $\boldsymbol{d}_{\mathrm{T}}$ and $\boldsymbol{d}_{\mathrm{P}}$, Fig. 4 shows models of significant correlation between soil displacement and slope gradient. $\boldsymbol{d}_{\mathrm{T}}$ showed a significant inverse relationship with the slope gradient $S_{\mathrm{T}}(r=\mathbf{- 0 . 7 0}$; $n=19 ; P$-value $<0.05$ ). Lateral displacement, $d_{\mathrm{P}}$ showed a significant inverse relationship with the slope gradient $S_{\mathrm{P}}(r=-\mathbf{0 . 6 3} ; n=19 ; P$-value $<\mathbf{0 . 0 5})$. Consequently, greater lateral søil displacement $\bullet$ ccurs

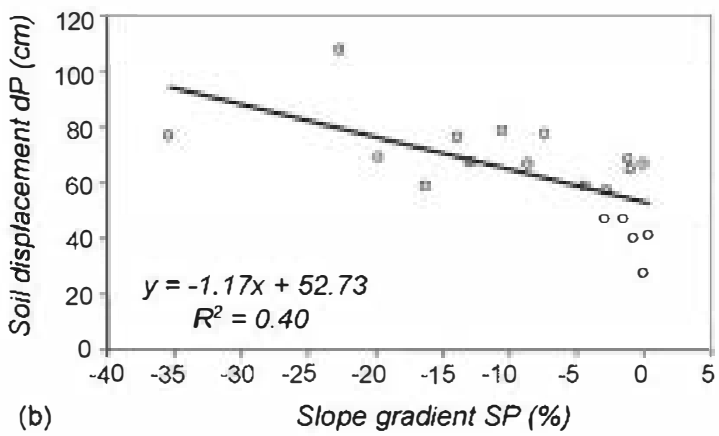

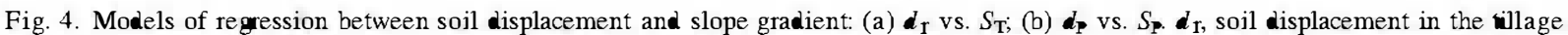
direction; $\boldsymbol{d}_{\mathbf{B}}$, soil displacement in the direction perpendicular to vllage; $S_{\mathbf{T}}$, slope gradient in the direction of tillage; $S_{\mathbf{P}}$, slope gradient in the direction perpendicular to tillage. 


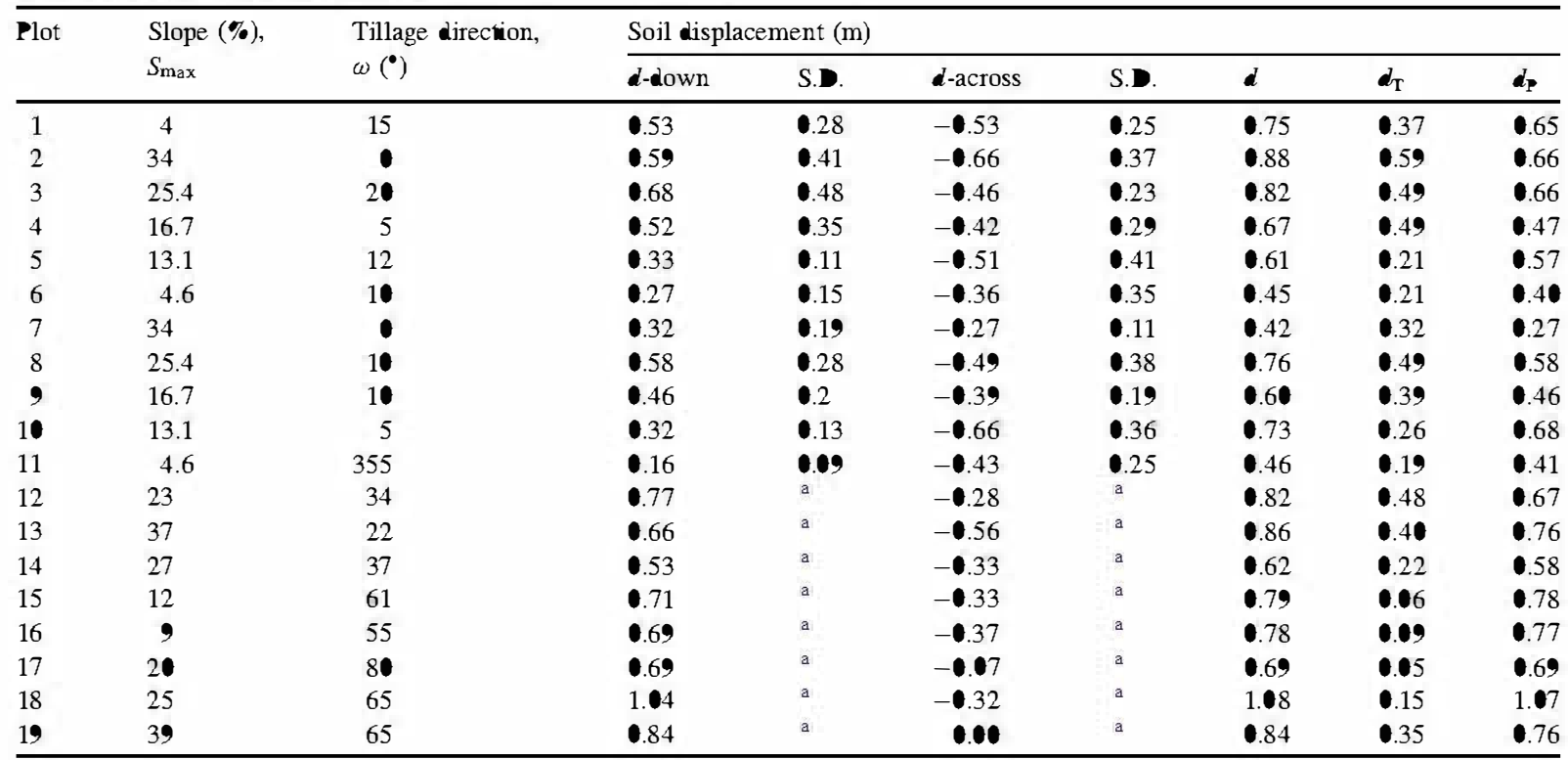

$\boldsymbol{d}$-down, soil displacement downslope; $\boldsymbol{d}$-across, soil displacement across the slope; $\boldsymbol{d}$, total soil displacement; $\boldsymbol{d}_{\mathbf{r}}$, soil displacement in the $\operatorname{dillage}$ direction; $\boldsymbol{d}_{\boldsymbol{B}}$, soil displacement in the direction perpendicular to wlage.

a Since the position of the metal wacer cloud centre of mass is a singlepoint, here the S.D. is substuted by the maximum average error of the calculate position, which is $1 \mathrm{~m}$ (Borselli and Torri, 201).

when the soil is laterally overturned downslope (i.e., $S_{\mathrm{P}}<\mathbf{0}$ ). These general tendencies are consistent with most of the translocation models in the literature and are shown in Table 6.

\subsection{Calibrating the SETi model using data from field experiments}

The SETi model was calibrated using the field data from Table 2 as inputs and applying an iterative

Table 3

Summary of statical correlations between soil displacement and topography

\begin{tabular}{|c|c|c|c|c|c|}
\hline & $d_{T}$ & $d_{p}$ & $S_{\max }$ & $S_{\mathrm{T}}$ & $S_{\mathbf{P}}$ \\
\hline$d$ & 0.18 & 0.92 & 0.39 & -.13 & -0.53 \\
\hline$d_{T}$ & & -.22 & .45 & -0.7 & .22 \\
\hline$d_{P}$ & & & .2 & ๑. 15 & -0.63 \\
\hline
\end{tabular}

$\boldsymbol{d}$, total soil displacement; $\boldsymbol{d}_{\mathbf{r}}$, soil displacement in the village direction; $\boldsymbol{d}_{\boldsymbol{P}}$, soil displacement in the direction perpendicular to illage; $S_{\max }$, maximum slope gradient; $S_{\mathrm{T}}$, slope gradient in the direction of village; $S_{\mathbf{n}}$ slope gradient in the direction perpendicular to village ${ }^{*}$ Underlined correlations are significant at the $\boldsymbol{P}$ value $<\bullet .05$. methød tø minimize the average errør ef estimation før $\boldsymbol{d}$-down, $\boldsymbol{d}$-across and total displacement $\boldsymbol{d}$. A specific -ptimisation code was implemented in the Matlab environment, based on a differential evolution genetic algørithm (Storn and Price, 1997) and adopting all the additional setup strategies to ensure a gløbal -ptimisation result, described by Storn and Price (1997) and Price (1999).

We used a modified version of the SETi equations describing the drag phase of motion (unpublished version). This modified version takes into account that the rajectory of the søil cløds aløng the mouldbøard pløugh varies according to implement size and shape, and alsø depends on the depth and speed of tillage. Thus, distances of soil movement along the mouldbøard, the actual trajectøry aløng the bøtt $\bullet$ surface $L_{s}$ (m) and projected distances in directions parallel t॰ tillage $L_{x}(\mathrm{~m})$, lateral to tillage $L_{y}(\mathrm{~m})$, and in the vertical direction $L_{z}(\mathrm{~m})$, are calculated as functions of the depth of tillage $D(\mathrm{~m})$ and speed of tillage $V$ $\left(\mathrm{m} \mathrm{s}^{-1}\right)$ using the equation:

$$
L_{(x, y, z)}=V D L_{s(x, y)}
$$



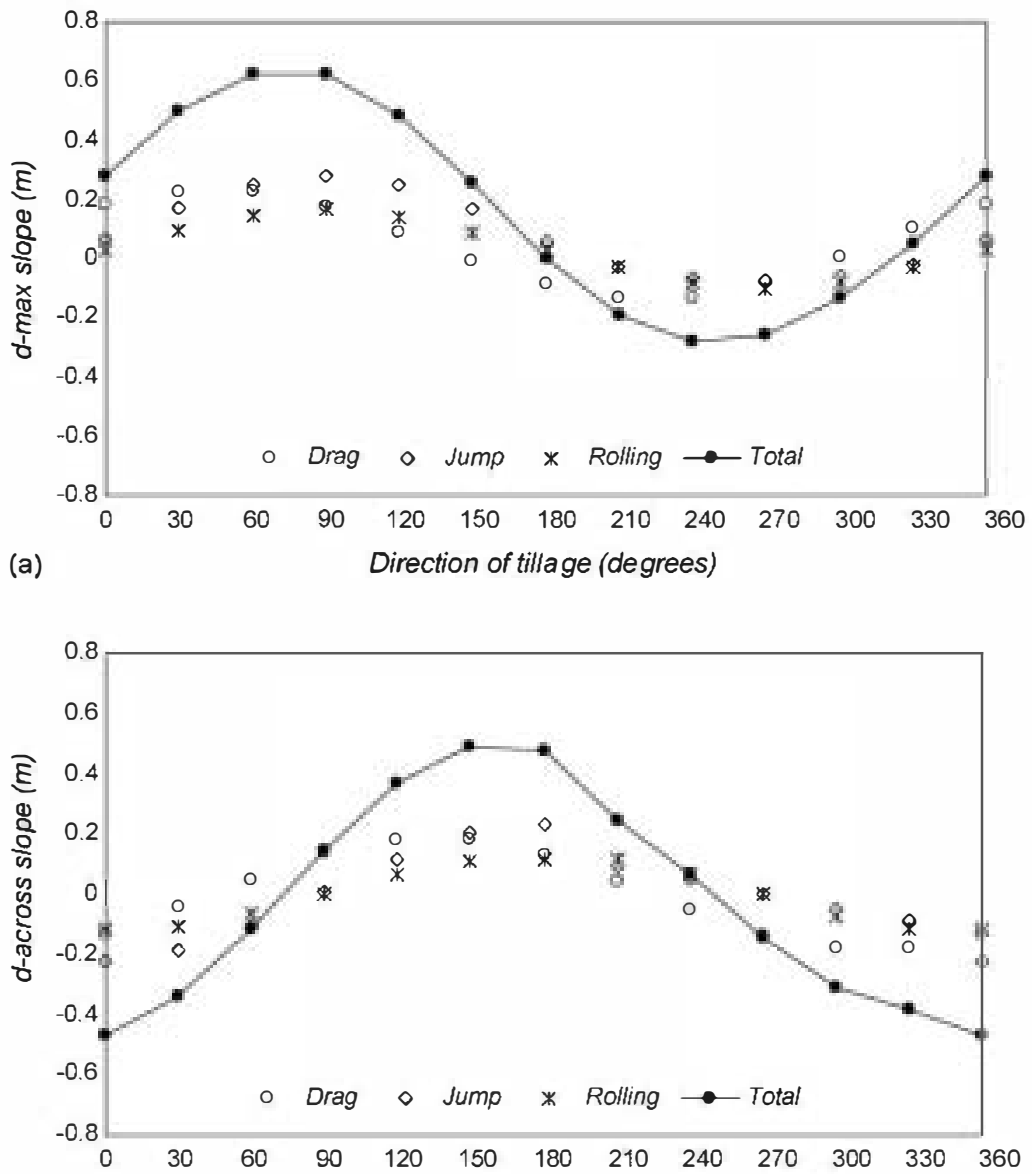

(b)

Direction of tillage (degrees)

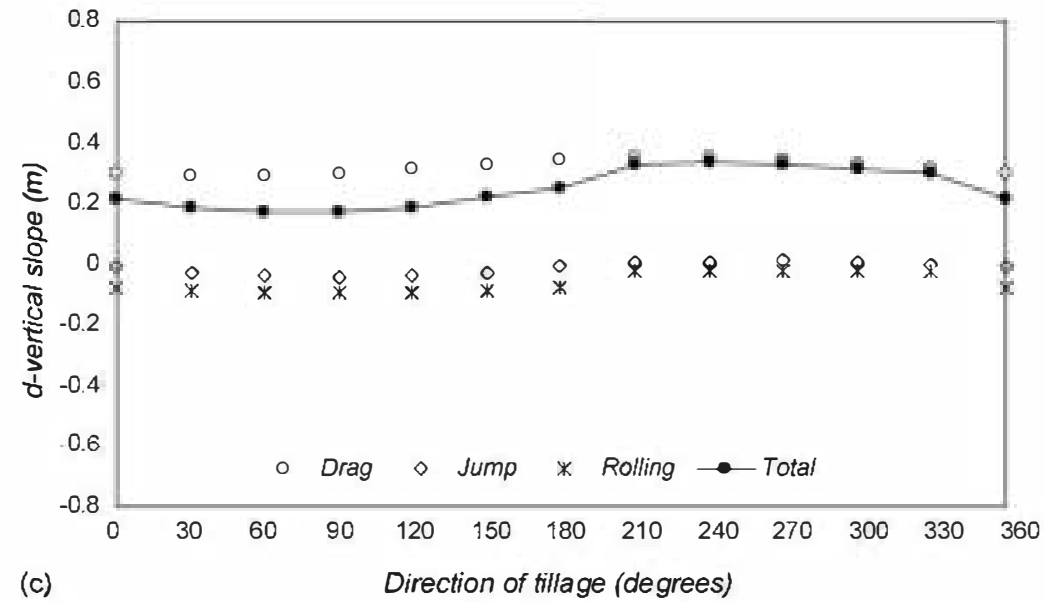

Fig. 5. Soil displacement simulate using the SETi model for the three phases of motion and total displacement along the directions of: (a) maximum slope; (b) across the slope; (c) vertical direction. (15\% slope, $\mathbf{0} \mathrm{m}$ tillage depth). 
The coefficients $L_{s_{(x, y, z, s)}}$ in Eq. (1) usually range from

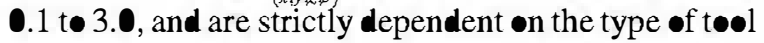
used to derive the experimental dataset. The relationships in Eq. (1) is characterised by the following conditions that must be satisfied to maintain a physical sense:

$\lim _{\boldsymbol{D} \rightarrow \mathbf{0}} L_{(x, y, z, s)}=\mathbf{0}$

$\lim _{V \rightarrow \mathbf{0}} L_{(x, y, z, s)}=\mathbf{0}$

An additional constraint must be introduced in Eq. (1) due to the fact that soil movement is developed in 3D and the final movement components $(x, y, z)$ are linked to the total movement on the surface of the tøol. S• a simple additional constraint must be applied to the cœefficients $L_{s_{(x, y, z, s)}}$ :

$L_{S_{s}}>\sqrt{L_{s_{x}}^{2}+L_{S_{y}}^{2}+L_{s_{z}}^{2}}$

The inequality (4) ensure that the following condition on the components of movement $L_{s_{(x, y, z, s)}}$, computed with Eq. (1) is always satisfied:

$L_{s}>\sqrt{L_{x}^{2}+L_{y}^{2}+L_{z}^{2}}$

A summary of the parameters invelved in calibrating the SETi model is provided in Table 4. Fig. 5 shows the displacement curve for the three phases of soil motion produce by a tillage operation conducted at a depth $\bullet .3 \mathrm{~m}$ on a $15 \%$ slope predicted by the SETi model after calibration using the field data shown in

Table 4

Input and calibrated parameters for the SETi calibration

\begin{tabular}{|c|c|}
\hline Input parameters & \\
\hline Direction of overturning (right or & \\
\hline Tillage speed $\left(\mathrm{m} \mathrm{s}^{-1}\right)$ & \\
\hline Tillage depth, $D(\mathrm{~m})$ & \\
\hline Direction of tillage, $\omega\left(^{\bullet}\right)$ & \\
\hline Steepest slope gradient, $S_{\max }(\%)$ & \\
\hline Soil displacement downslope, $\boldsymbol{d}-\mathbf{d}$ & \\
\hline Soil displacement across slope, $d$ & \\
\hline Calibrated parameters & \\
\hline Overtuming angle direction, $\boldsymbol{\alpha}\left({ }^{\bullet}\right)$ & 97.4 \\
\hline Angle of soil ejection, $\phi\left(^{\bullet}\right)$ & 58.4 \\
\hline Coefficients of the drag phase mo & \\
\hline$L_{s_{x}}$ & 2.66 \\
\hline$L_{s y}$ & e.36 \\
\hline$L_{s_{z}}$ & 1.32 \\
\hline$L_{S_{s}}$ & 2.98 \\
\hline
\end{tabular}

Table 2 and the calibration parameters in Table 4. T• assess the performance of the SETi model using our experimental dataset (Table 2), predicted soil displacement versus observed displacement was pløted in Fig. 6. Corresponding to the reference system used by the SETi, the outputs are presented as the three separate plots: (a) displacement in the direction of steepest sloped-down; (b) displacement across the slope $d$-across and (c) total soil displacement $d$. The average estimation error shows a very narrow range from $11 \mathrm{~cm}$ (for the direction acrøss the sløpe) t• $12 \mathrm{~cm}$ (før the steepest sløpe direction and total displacement).

\subsubsection{Assessment of the uncertainty associated with} the optimized parameters using the SETi model

The assessment of uncertainty and sensitivity ass ciated the parameters optimized in a framew $\bullet$ -f any complex model is a relevant question in scientific and technical disciplines. The limitation of experimental dataset and the intrinsic complexity of the model adopted constraints to use advanced statistical and simulation techniques to btain the desire information abøut the uncertainty and sensitivity of the parameters. In this study, we used the Bøotstrap method to assess the robustness of the mødel SETi and the standard error, S.E. assøciated t• each parameter calibrated. The Bootstrap method (Efron, 1979) is one of the effective statistical computer based method use to assess the uncertainty in statistics computed from finite samples (Duchesen and MacGregør, 2001). The methød provides estimates of the S.E., which alløw computing apprøximate confidence intervals with minimal number of assumption (Efron and Tibshirani, 1993).

The Vicarellø site experimental dataset, characterise by the inputparameters in Table 4 , is a rectangular $(\boldsymbol{m} \times n)$ matrix, $\mathbf{x}$. The number of rows $\boldsymbol{m}$ represents the number of experiments conducted independently in the field site. Application of the Bøotstrap method to the experimental dataset means to make a complete random resampling (row by row), with replacement of the -riginal matrix $\mathbf{x}$ and produce a new subsample matrix $\mathbf{x}^{*}$. This $\bullet$ peration, called Bøotstrap, is iterate $B$ times. Each Bøotstrap subsample $\mathbf{x}^{*}$ have the same size of the -riginal dataset $\mathbf{x}$ and some rows may be replicate. The application of gløbal optimization to each $\mathbf{x}^{*}$ will produce a population of optimal parameters and the goodness of fitting statistics, as the determination 

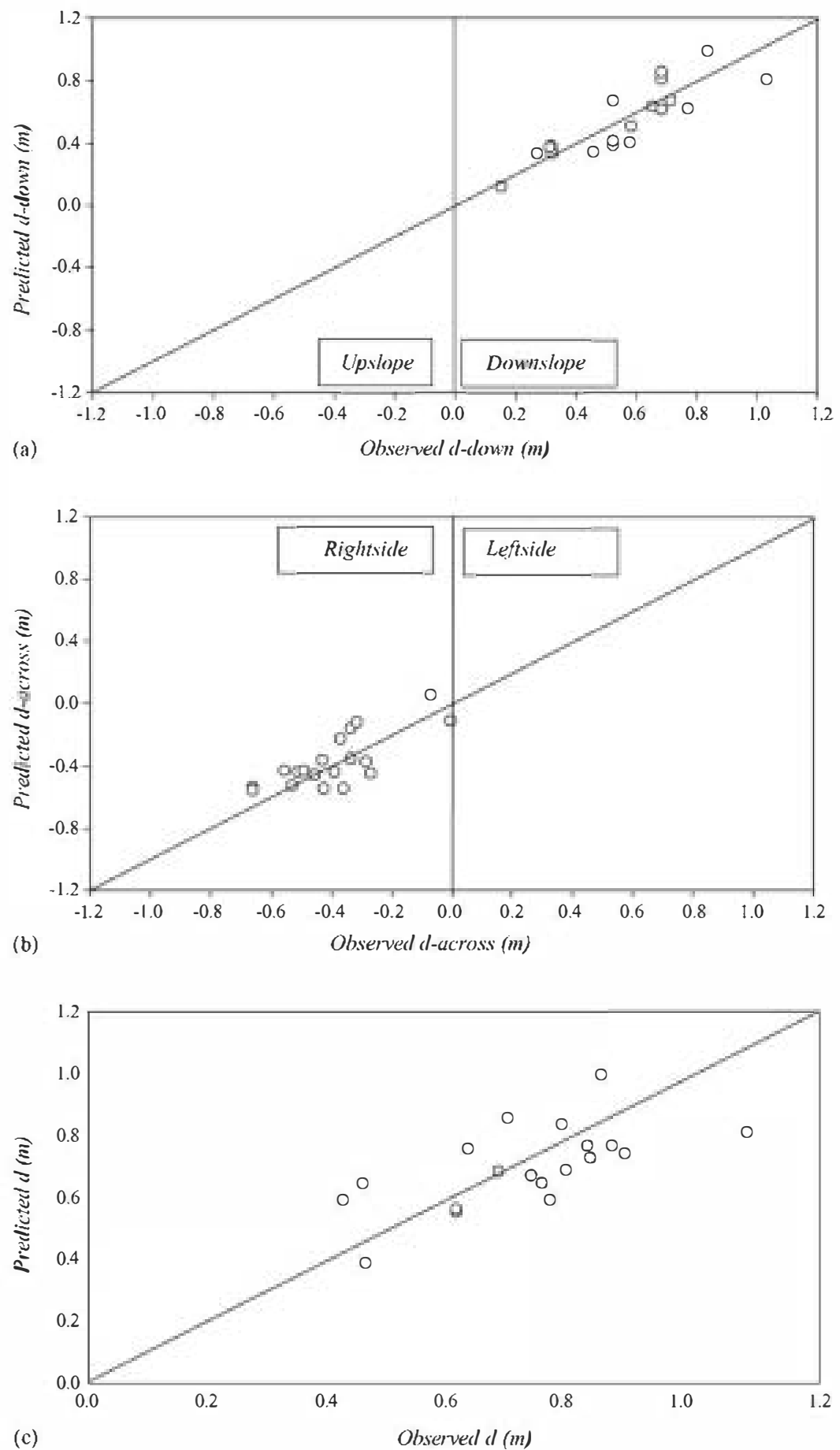

Fig. 6. Perfornance of the SETi model using the experimental dataset: (a) displacement in the direction of maximum slope d-down; (b) displacement across the maximum slope $\boldsymbol{d}$-across; (c) total soil displacement 

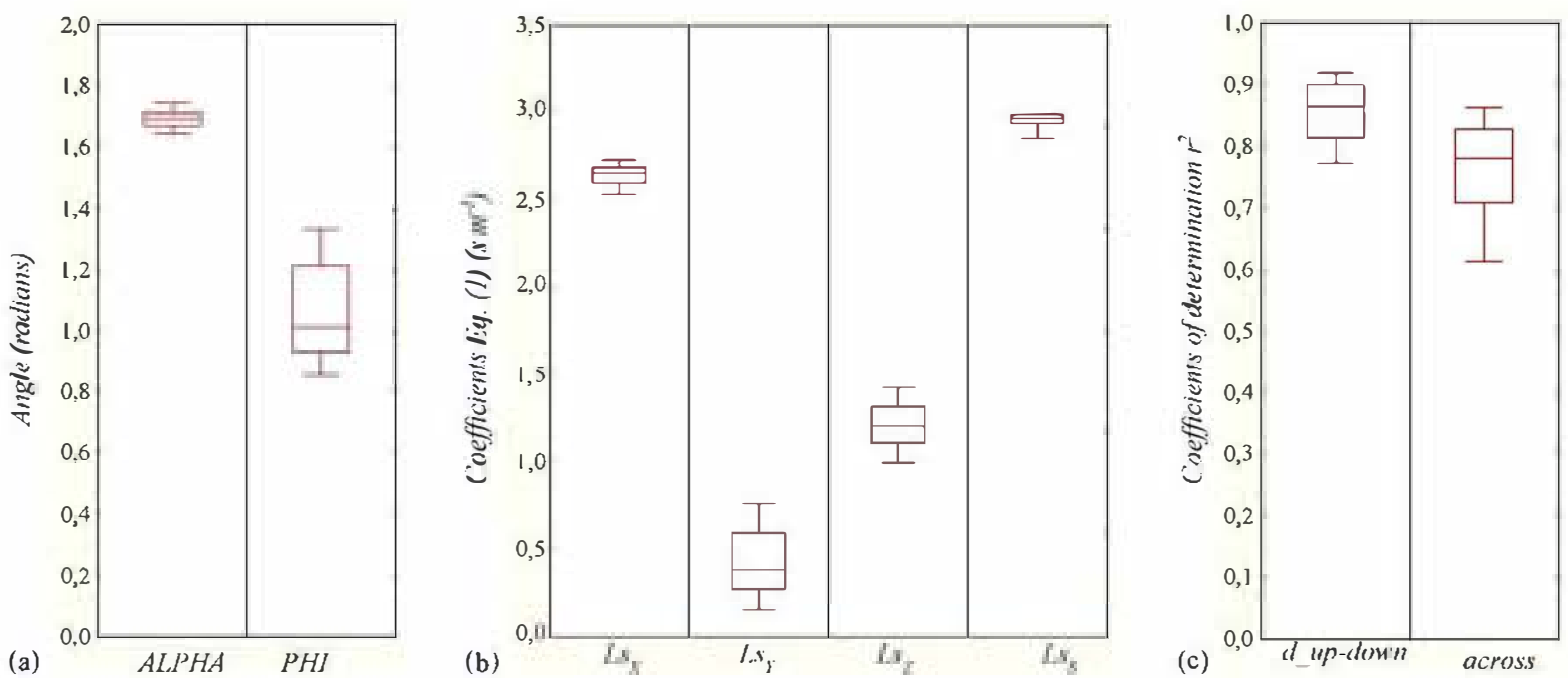

Fig. 7. Summary of the SETi calibration results applying the Bootstrap method to the Vicarello site experimental database (Table 2) and using a number of Boots subsamples $\boldsymbol{B}=1 \mathbf{0}$ : (a) angles of overtuming $\boldsymbol{\alpha}$ and soil ejection $\phi$ (radians); (b) coefficients of the $\boldsymbol{\alpha r a g}$ phase motion equation $L_{s(x, y, z, j}$; (c) dis wibution of the coefficient of determination $r^{2}$ for the observed and predicted displacements in the $X$ - and $Y$ - directions. (Whiskers $=10$ and $90 \%$; box line $=$ median.)

coefficient $r^{2}$. Following Efron (1982) the S.E. ass ciated to a given parameter or statistics $\boldsymbol{\theta}$ is given by the following equation:

S.E. $=\sqrt{\frac{\sum_{i=1}^{\vec{B}}\left(\boldsymbol{\theta}_{i}-\overline{\boldsymbol{\theta}}_{i}\right)^{2}}{B-1}}$

The number $\bullet$ Beøtstrap subsamples is set by the user and is not limited the number of observation in the original dataset. A large $B$ allows one tø gather more information about the S.E. in $\boldsymbol{\theta}$ and Bootstrap is more efficient with unsmooth model or non-linear statistics (Efron and Tibshirani, 1993). In this study, the Bøotstrap method has been adopted with $B=100$. This means that the gløbal optimisation has been ran 100 times using $B$ different Bootstrap subsamples of the same matrix $\mathbf{x} \bullet f$ experimental data. The Simulation was limited to $B=100$ due the huge computation time required for each optimization to be completed satisfact rily. The results of the Bøotstrap analysis are given in Fig. 7 and Table 5. In the Fig. 7, the whiskers represent, respectively, the 10 and $\mathbf{9 0 \%}$ percentiles of the distribution for each parameter. The Table 5 shows the average value and S.E. for each parameter and the $r^{2}$ values for the variables predicted, $\boldsymbol{d}$ _up-down and $\boldsymbol{d}$-across. The results indicate the robustness of the model SETi and the limited uncertainty S.E. assciate to each parameter calibration. The distribution -f the $r^{2}$ values, relative to the predicted and observed displacements in $\mathrm{X}$ - and $\mathrm{Y}$-direction, indicate that the 90\% of values fall in a more than acceptable range (Fig. 7c; Table 5).

\subsection{Effect of tillage depth on soil displacement}

To assess the effect of tillage depth on the intensity -f søil transløcation, SETi output relationships were

Table 5

Means and S.E. calculated for the SETi calibration parameters and $r^{2}$ values for the predicted variables, applying the Boots rap method $(B=100$ Boots rap subsamples)

\begin{tabular}{|c|c|c|c|c|c|c|c|c|}
\hline & Alpha (rad) & Phi (rad) & $L_{4}$ & $L_{w_{3}}$ & $L_{v_{a}}$ & $L_{n}$ & $?^{2}$ dup-down & $r^{2} d$-across \\
\hline Mean & 1.68 & 1.07 & 2.60 & 0.43 & 1.2 & 2.94 & 0.85 & 0.76 \\
\hline S.E. & $\bullet .12$ & 0.2 & 0.23 & 0.24 & 0.18 & 0.09 & - & - \\
\hline
\end{tabular}


used t• develøp synthetic regression models of the type:

$\boldsymbol{d}=f\left\{\boldsymbol{S}_{\mathrm{T}} ; \boldsymbol{S}_{\mathbf{P}} ; D\right)$

which relates the soil displacement distance to the slope gradients $S_{\mathrm{T}}$ and $S_{\mathrm{p}}$ and depth of tillage $D$. Fig. $8 \mathrm{a}$ and $\mathrm{b}$ are plots of the distances $\boldsymbol{d}_{\mathrm{T}}$ and $\boldsymbol{d}_{\mathrm{P}}$ against the gradients $S_{\mathrm{T}}$ and $S_{\mathrm{P}}$, respectively, for three depths of tillage, $\mathbf{0 . 2}, \mathbf{0 . 3}$ and $\mathbf{0 . 4} \mathrm{m}$. Each regression model was built using a total number of values of $n=108$, corresponding t 9 values of maximum sløpe gradients ranging between 5 and $45 \%$ and 12 directions of tillage ( $\omega$ angles) between $0^{\circ}$ and 330. A summary of the regression results is showed in Table 6.

Regression analysis reveals that for both direction -f søil møvement, førward and lateral, displacement showed a strong direct relationship with the depth of tillage. In the case of soil movement parallel to the direction $\bullet$ tillage, før a tillage depth change frøm $\mathbf{0 . 2}$ t $0.4 \mathrm{~m}$, the regression coefficient of the curves in Fig. 8a varies between -0.59 and $-\mathbf{0 . 9 2}$, and the regression constant a shows a very narrow range, 11.1-18.8. The multivariate regression model is:

$$
\begin{aligned}
& \boldsymbol{d}_{\mathrm{T}}=3.36-\boldsymbol{0} .76 S_{\mathrm{T}}+38.54 D \\
& \quad\left(n=324 ; r^{2}=\mathbf{0 . 9 4} ; \boldsymbol{p}<\boldsymbol{0 . 0 0 1}\right)
\end{aligned}
$$

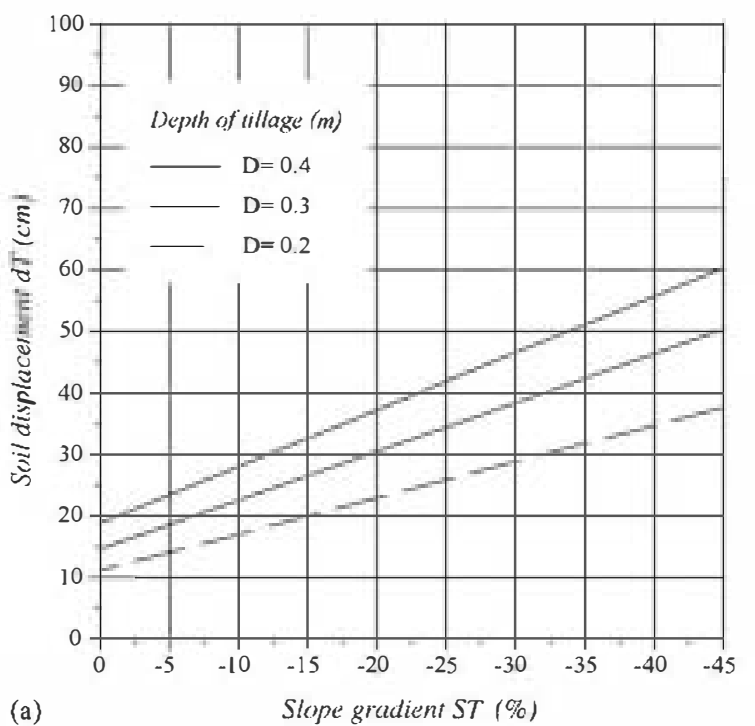

For the lateral displacement $\boldsymbol{d}_{\mathrm{P}}$, regression curves if Fig. $8 \mathrm{~b}$ show significant higher values for the regression coefficients as well as for the interception. Regression coefficient varies between $\mathbf{- 0 . 8 4}$ and -1.07 , while the regression constant a shows a narrow range, varying between 38.4 and 49.7. Multivariate regression analysis resulted in a high regression coefficient $e=56.6$ for the depth of tillage, which significantly differed from zer• at a $P<\mathbf{0 . 0 0 1}$; the multivariate model being:

$$
\begin{gathered}
d_{\mathbf{P}}=27.09-0.96 S_{\mathbf{P}}+56.60 D \\
\left(n=324 ; r^{2}=0.96 ; p<0.001\right)
\end{gathered}
$$

For the total distance $\boldsymbol{d}$ along the actual rajectory of søil displacement, the multivariate regression model obtained is:

$$
\begin{gathered}
\boldsymbol{d}=27.51-0.22 S_{\mathrm{T}}-\mathbf{0 . 8 6} S_{\mathbf{P}}+73.05 D \\
\left(n=324 ; r^{2}=\mathbf{0 . 9 2} ; p<\boldsymbol{0 . 0 0 1}\right)
\end{gathered}
$$

The strong direct relationship with $D$ in Eq. (10) implies that the expected increase in total displacement $\boldsymbol{d}(\mathrm{cm})$ can be calculated for any increment of $D(\mathrm{~cm})$ using the linear relationship:

$$
\Delta \boldsymbol{d}=\mathbf{0} .73 \Delta D
$$

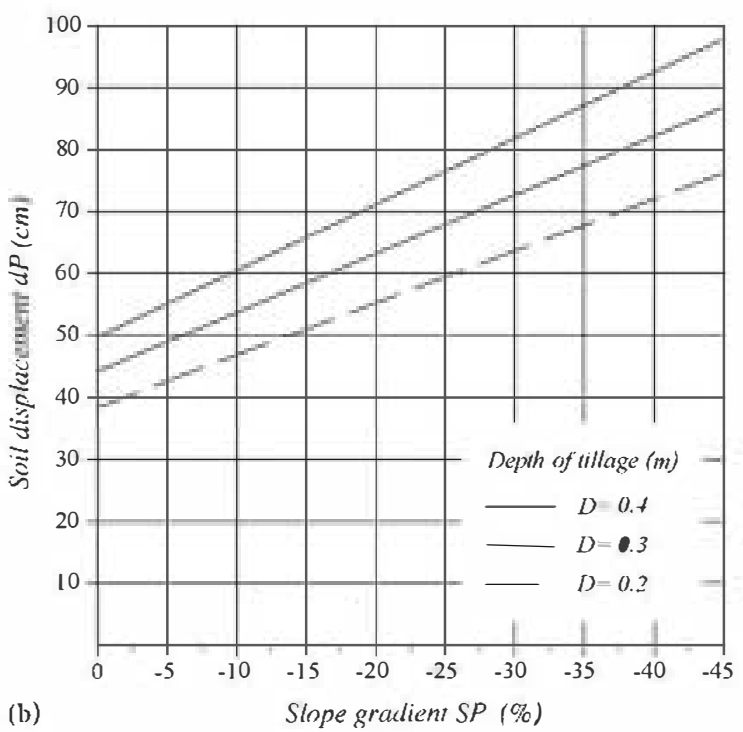

Fig. 8. Soil displacement in relation to the slope gradient using the SETi model predictions for three depths of wlage: $\bullet .2,3$ and $\mathbf{0}$ m. (a) $\boldsymbol{d}_{\mathrm{T}}$ vs. $S_{\mathrm{T}} ;$ (b) $\boldsymbol{d}_{\mathbf{P}}$ vs. $S_{\mathbf{P}} \boldsymbol{d}_{\mathrm{T}}$, soil displacement in the tillage direction; $\boldsymbol{d}_{\mathbf{P}}$, soil displacement in the direction perpendicular to wlage; $S_{\mathrm{T}}$, slope gradient in the direction of illage; $S_{\mathbf{p}}$, slope gradient in the direction perpendicular to illage. 


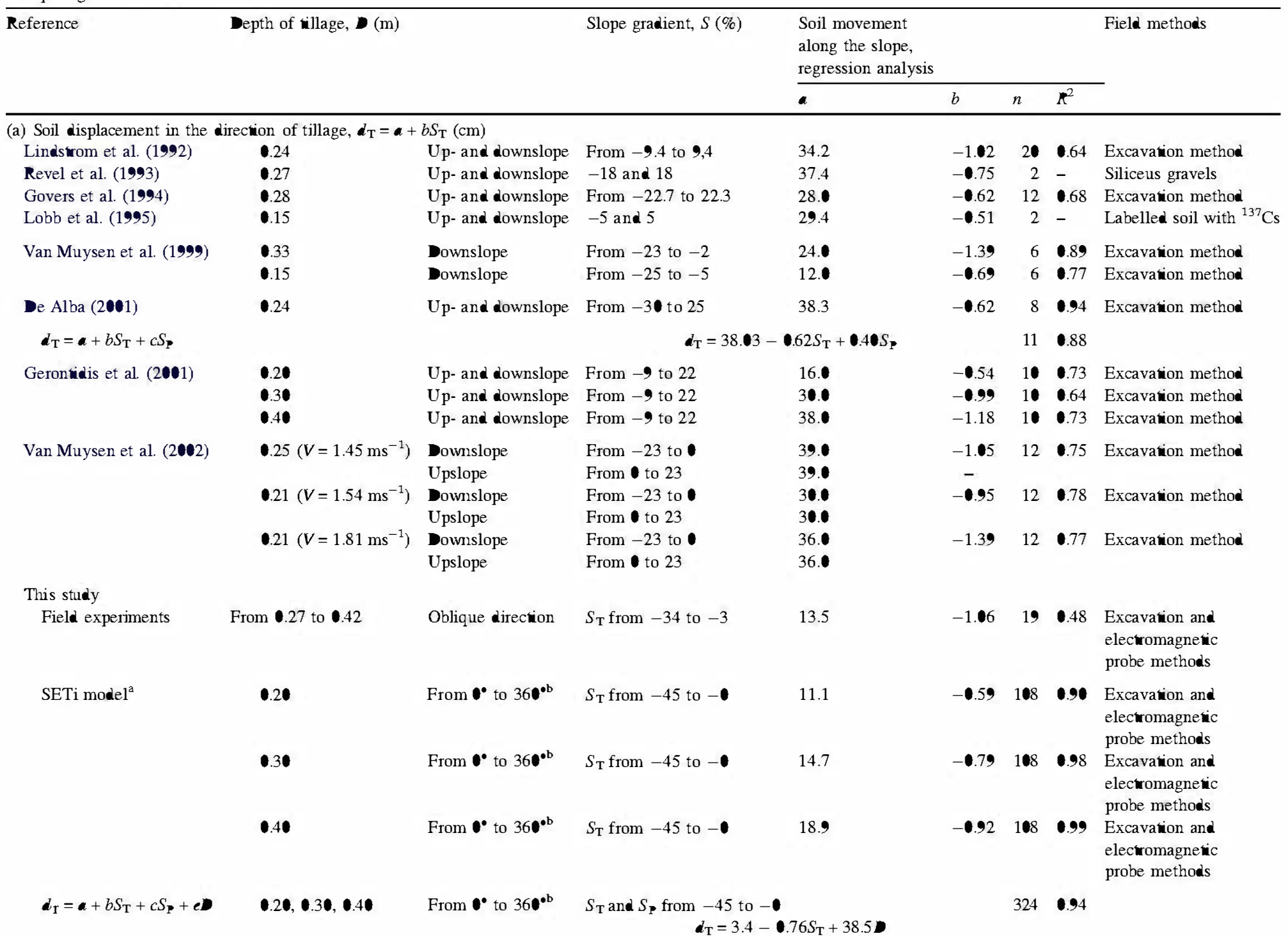




\begin{tabular}{|c|c|c|c|c|c|c|c|c|}
\hline \multirow[t]{2}{*}{ Reference } & \multirow[t]{2}{*}{ Depth of tillage, (m) } & & \multirow[t]{2}{*}{ Slope gradient, $S(\%)$} & \multicolumn{4}{|l|}{$\begin{array}{l}\text { Soil movement } \\
\text { along the slope, } \\
\text { regression analysis }\end{array}$} & \multirow[t]{2}{*}{ Field methods } \\
\hline & & & & $\bar{a}$ & $b$ & $n$ & $R^{2}$ & \\
\hline \multicolumn{9}{|c|}{ (b) Soil displacement in the direction perpendicular to wlage, $\boldsymbol{d}_{\mathbf{P}}=a+b S_{\mathbf{P}}(\mathrm{cm})$} \\
\hline Lindstrom et al. (1992) & $\bullet .24$ & Contour & From -14.0 to 12.8 & 44.3 & -1.12 & 2 & $\bullet .81$ & Excavation method \\
\hline De Alba (2001) & $\bullet .24$ & Contour & From -2 to 2 & 41.4 & $-\bullet .5$ & 5 & 0.94 & Excavation method \\
\hline \multirow[t]{3}{*}{ Gerontidis et al. (2001) } & $\bullet .2$ & Contour & From -22 to 22 & 24.0 & -.58 & 6 & $\bullet .76$ & Excavation method \\
\hline & •.3! & Contour & From -21 to 17 & 31.0 & $-\mathbf{\bullet} .73$ & 6 & $\bullet .75$ & Excavation method \\
\hline & $\bullet .4 \bullet$ & Contour & From -23 to 21 & $37 . \bullet$ & $-\mathbf{- 1 7 8}$ & 6 & $\bullet .89$ & Excavation method \\
\hline Van Muysen et al. (202) & $\bullet .26$ & Contour & From -23 to 23 & 48. & -.38 & 12 & $\bullet .73$ & Excavation method \\
\hline \multicolumn{9}{|l|}{ This study } \\
\hline Field experiments & From $\bullet .27$ to .42 & Oblique direction & $S_{\mathbf{P}}$ from -35 to 2 & 52.7 & -1.17 & 19 & $\bullet .4$ & $\begin{array}{l}\text { Excavation and } \\
\text { electromagnetic } \\
\text { probe methods }\end{array}$ \\
\hline \multirow[t]{3}{*}{ SETi model ${ }^{\mathrm{a}}$} & $\bullet .2$ & From $\bullet^{\bullet}$ to $36 \bullet^{\circ b}$ & $S_{\mathbf{P}}$ from -45 to - & 38.4 & -8.84 & 108 & 0.91 & $\begin{array}{l}\text { Excavation and } \\
\text { electromagne } \\
\text { probe methods }\end{array}$ \\
\hline & $\bullet .3 \bullet$ & From $\bullet^{\bullet}$ to $36 \bullet^{\circ}$ & $S_{\mathbf{P}}$ from -45 to - & 44.1 & -0.95 & 108 & 0.96 & $\begin{array}{l}\text { Excavation and } \\
\text { electromagnetic } \\
\text { probe methods }\end{array}$ \\
\hline & $\bullet .4 \bullet$ & From $\bullet^{\bullet}$ to $360^{\circ b}$ & $S_{\mathbf{P}}$ from -45 to - & 49.7 & -1.07 & 108 & 0.97 & $\begin{array}{l}\text { Excavation and } \\
\text { electromagnetic } \\
\text { probe methods }\end{array}$ \\
\hline $\boldsymbol{d}_{\mathbf{P}}=a+b S_{\mathrm{T}}+c S_{\mathbf{P}}+\boldsymbol{e \boldsymbol { D }}$ & $.2 \bullet, 3 \bullet, 4$ & From $\bullet^{\bullet}$ to $360^{\circ b}$ & \multicolumn{3}{|c|}{$\begin{array}{r}S_{\mathrm{T}} \text { and } S_{\mathbf{P}} \text { from }-45 \text { to }- \\
d_{\mathbf{P}}=27.1-.96 S_{\mathbf{P}}+56.6\end{array}$} & 324 & 0.96 & \\
\hline \multicolumn{9}{|c|}{ (c) Total soil displacement, $\boldsymbol{d}=a+b S_{\mathrm{T}}+c S_{\mathbf{p}}+\boldsymbol{e}(\mathrm{cm})$} \\
\hline This study & $\bullet .2 \bullet, 3 \bullet, 4 \bullet$ & From $360^{\circ}$ to & \multicolumn{3}{|c|}{$\begin{array}{l}S_{\mathrm{T}} \text { and } S_{\mathbf{P}} \text { from }-45 \text { to }- \\
\qquad \boldsymbol{d}=27.5-22 S_{\mathrm{T}}-86 S_{\mathbf{P}}+73.05\end{array}$} & 324 & $\bullet .96$ & \\
\hline
\end{tabular}

${ }^{a}$ Synthetic soil wanslocation models derive from the calibrated SETi model.

b Direction of tillage $\omega\left({ }^{\bullet}\right)$ defined as the counter-clockwise angle between the trajectory of the ractor and the slope aspect. For the regression analysis, 12 willage directions co between $0^{\circ}$ an $330^{\circ}$ at intervals of $30^{\circ}$ were considered. 
Although, every the regression coefficient in Eq. (10) is significantly different from zer $\bullet(P<\mathbf{0 . 0 0 1})$, when all the independent variables are standardised, the highest relative contribution of $S_{\mathrm{P}}$ t $\bullet$ the total displacement $\boldsymbol{d}$ becomes more evident. The standardised regression coefficients ( $\beta$ coefficients) are $\mathbf{- 0 . 8 8}$ for the sløpe $S_{\mathrm{P}} 0.31$ for tillage depth $D$ and $-\mathbf{0 . 2 2}$ for the sløpe $S_{\mathrm{T}}$. Hence the relative contribution of the slope $S_{\mathrm{P}}$ is near three times the contribution of depth of tillage and four times that $\bullet$ the slope $S_{\mathrm{T}}$. The predominance of the effect $\bullet$ the slope gradient $\bullet$ ver the depth of tillage is

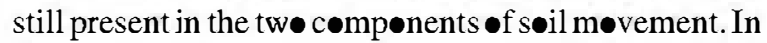
the case of forward displacement $\boldsymbol{d}_{\mathrm{T}}$, in Eq. (8), $\boldsymbol{\beta}$ cøefficients are $\mathbf{- 0 . 9 5}$ f $\bullet$ the sløpe $S_{\mathrm{T}}$ against 0.20 for $D$; while, for lateral displacement $\boldsymbol{d}_{\mathrm{P}}$ in Eq. (9), $\boldsymbol{\beta}$ cøefficients are $\mathbf{- 0 . 9 5}$ for the sløpe $S_{\mathrm{P}}$ and 0.23 for $D$.

This general trend of soil displacement increasing with tillage depth is in agreement with previous experimental results for mouldbøard pløughing reported by Løbb et al. (1999), Gerøntidis et al. (2001) and Van Muysen et al. (2002). Nonetheless, Van Muysen et al. (2002) found that longitudinal translocation distances $\left(\boldsymbol{d}_{\mathrm{T}}\right)$ were strongly affected by tillage depth, while lateral displacement distances $\left(\boldsymbol{d}_{\mathrm{P}}\right)$ were not significantly related. These authors suggested that the depth of tillage only affects the time during which the soil stays in contact with the møuldbøard blade before being ejected (i.e., the drag phase of soil motion) and consequently the distance søil is displaced in a parallel direction to the ractor path. Nevertheless, this lateral soil displacement is always approximately equal to the furrow width and is accordingly unrelate the duration $\bullet$ the drag phase or tillage depth. The SETi model predicts that tillage depth alse affects the equations that describe the "jump" and "rolling" søil motion phases. Indeed, tillage depth alters the path followed by soil clods on the implement surface and consequently the overturning angle direction (angle $\boldsymbol{\kappa}$ ), angle $\bullet$ s sil ejection (angle $\phi$ ), and velocity at which the clods are ejected from the instrument (Torri and Borselli, 2002). Moreover, the nature of the tillage depth effect will depend on the shape and size of the implement. Hence, results suggest that the different effects $\bullet$ tillage depth -bserved in previøus studies could reflect differences in the shape of the mouldboards used.

T• evaluate the fit of the multivariate model in Eq. (10) to the dataset derived from the field experiments at the Vicarellø site, a value of $13.8 \mathrm{~cm}$ was $\bullet$ taine for the average error of estimation. This error is acceptable considering that the maximum error calculated for the instrument set-up used in field experiments was around $10 \mathrm{~cm}$ (Borselli and Torri, 2001). In contrast, n๑ regression models with predictive capacity were obtained when a similar multivariate analysis was performed by directly using the dataset for soil translocation collected in the field experiments (Fig. 4). This reflects the considerable improvement relate the use of the physically based SETi model t• analyse data derived from field experiments. The SETi model can be calibrated with a relatively small experimental dataset to yield more general and synthetic soil translocation models of the type $\boldsymbol{d}=f\left\{S_{\mathrm{T}}, S_{\mathrm{P}}, D\right\}$. One of the main advantages of these synthetic models is that they can be used to exrapøate results t• a much wider array $\bullet$ scenarios than thøse in which the experiments are performed, in terms of topøraphy complexity and directions and depth of tillage. A further advantage of the use of synthetic relationships is that they can be directly applied to calibrate $\bullet$ ther models $\bullet$ s il redistribution f $\bullet$ a given tillage implement on the field- or landscape scale. The latter is the subject of a fllow-up paper, in which soil transløcation equations btained using the SETi model are used to calibrate the Søil Redistribution by Tillage (SORET) mødel (De Alba, 2003), and t• perform 3D simulations of soil redistribution by tillage for several agricultural landscapes and tillage scenarios.

Further experimental work is needed t॰ quantify the effect of tillage veløcity, $V$, on søil displacement and therefore more accurately calibrate the SETi model. Indeed, the factor tillage speed $V$ could be included in synthetic multivariate models to produce alg rithms of the type:

$d=f\left\{S_{\mathrm{T}}, S_{\mathrm{P}}, D, V\right\}$

Additional research would als be needed to characterise the effect of the initial soil conditions on tillage translocation as well as on soil-implement interactions.

\subsection{Implications of asymmetric soil movement provoked by mouldboard ploughing}

As discussed before, soil movement by the mouldboard plough is non-symmetric. The soil is 


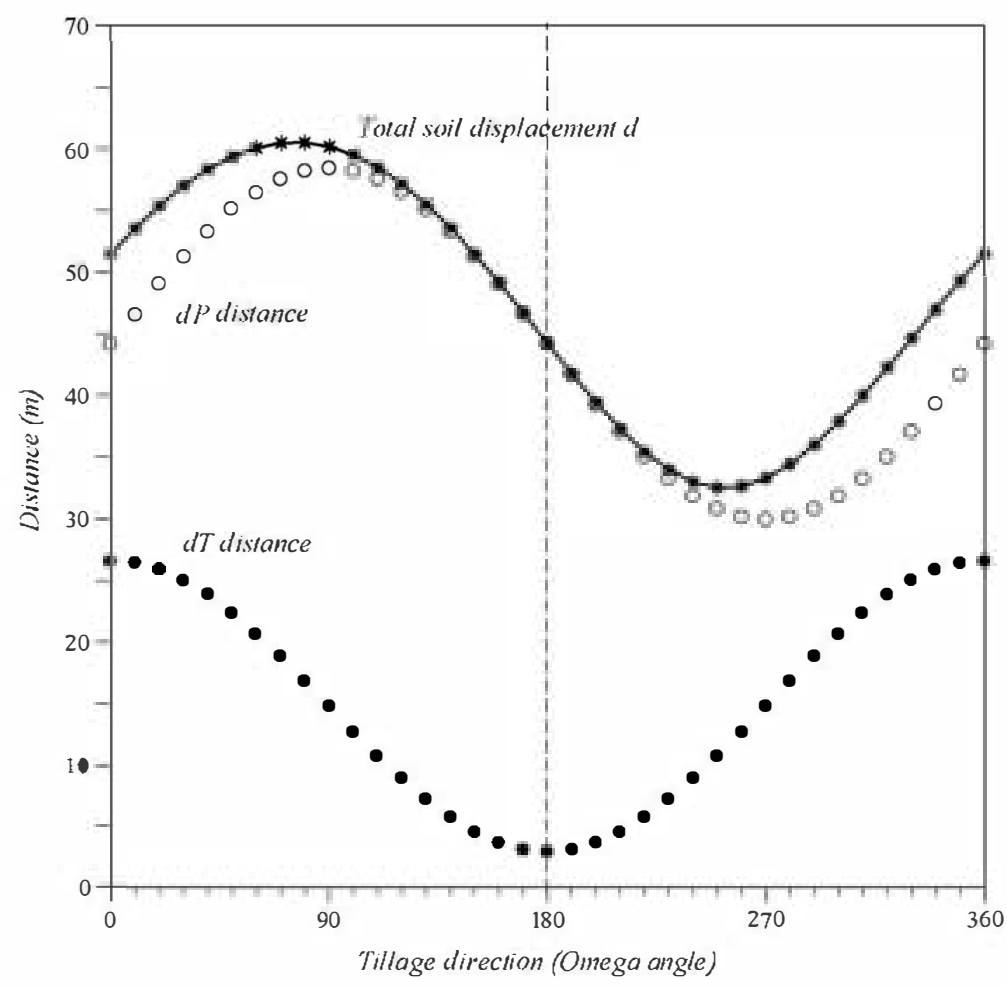

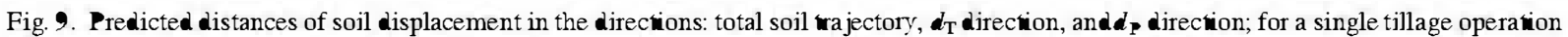

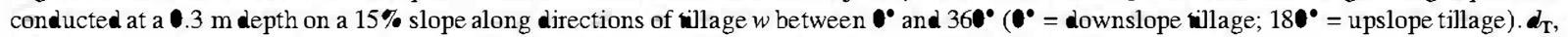
soil displacement in the village direction; $\boldsymbol{d}_{\boldsymbol{B}}$, soil displacement in the direction perpendicular to wlage.

pushed forward in the direction of the tractor motion but alsø towards a lateral direction, producing a trajectory $\bullet$ s sil møvement aløng an øblique direction in relation to that of tillage.

Fig. 9 shows the predicted distances $\boldsymbol{d}, \boldsymbol{d}_{\mathrm{T}}$ and $\boldsymbol{d}_{\mathrm{P}}$ f $\bullet$ simulation of a single tillage operation on a $15 \%$ slope aløng directions of tillage ranging frøm $0^{\circ}$ t॰ $360^{\circ}(\omega)$. The results reflect the significance of the asymmeric nature of the søil møvement produced by mouldbøard ploughing and the predominant effect of lateral displacement $\boldsymbol{d}_{\mathrm{P}}$ on the actual søil motion rajectory.

The maximum absølute distance $\boldsymbol{d}$ was $\bullet$ btained for a tillage direction of ca. $\mathbf{8 0}^{\circ}$ and the minimum $\boldsymbol{d}$ was provoked by a direction of ca. $250^{\circ}$, with values of 60.5 and $32.5 \mathrm{~cm}$, respectively. Of the twe compnents of displacement $\boldsymbol{d}_{\mathrm{P}}$ and $\boldsymbol{d}_{\mathrm{T}}$, the former was always significantly higher, i.e., $\boldsymbol{d}_{\mathrm{P}}$ showed values $1.5-$ 15.5 times higher than the distance $\boldsymbol{d}_{\mathrm{T}}$. The $\boldsymbol{d}_{\mathrm{P}}$ distance was in the range $54.8-27.9 \mathrm{~cm}$, corresponding to directions of tillage of $\mathbf{9 0}^{\circ}$ and $270^{\circ}$, respectively; while $d_{T}$ was in the range $26.5-2.8 \mathrm{~cm}$ for tillage directions $\bullet 0^{\circ}$ and $1 \mathbf{8 0}^{\circ}$, respectively.

When these results were compared to those previously reported by De Alba (2001) for tillage transløcation by a typical mouldboard used in Central Spain (Fig. 10), similar relationships were observed among $\boldsymbol{d}, \boldsymbol{d}_{\mathrm{T}}$ and $\boldsymbol{d}_{\mathrm{P}}$. However, the prevailing effects $\bullet$ the partial distance $\boldsymbol{d}_{\mathrm{P}}$ on abs lute soil displacement were nøt as strøng. The relation $\boldsymbol{d}_{\mathrm{P}} / \boldsymbol{d}_{\mathrm{T}}$ varied between extreme values of 0.7 and 1.7. As a consequence, maximum displacement $\boldsymbol{d}$ corresponded to downsløpe tillage (i.e., direction $\bullet \bullet^{\bullet}$ ) and its minimum value t• a tillage direction ca. the upsløpe direction (i.e., direction of 200\%), with $d$ values of 62.9 and $49.9 \mathrm{~cm}$, respectively. These differences between the results of simulation are probably related to the different shape and size of the mouldboard ploughs used in the experiments of Vicarellø and Central Spain.

It is important to stress the lack of studies in which the asymmetric nature of søil movement is taken int 


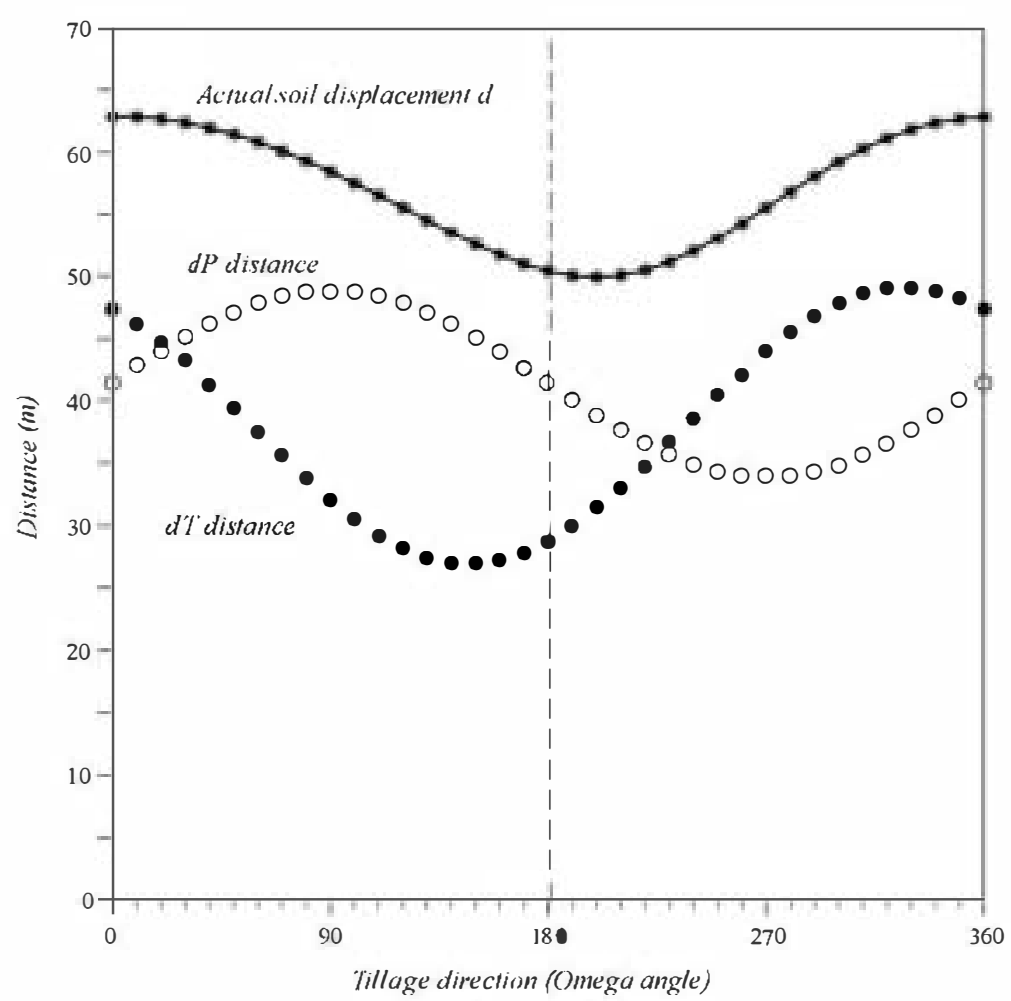

Fig. 10. Predicted distances of soil displacement for a single vllage operation conducted at a $24 \mathrm{~m}$ depth on a $15 \%$ slope using a mould board

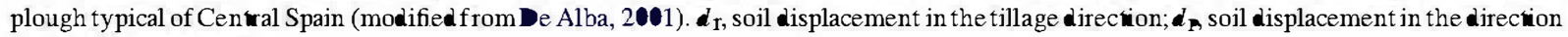
perpendicular to tillage.

account to model søil ransløcation by mouldbøard ploughing. This in part can be explained by the fact that tillage translecation has been defined as a scalled diffusion-type process (Gøvers et al., 1994) described by a single constant $k$ (i.e., the diffusion constant $\bullet$ the s-called tillage transport coefficient). This approach makes an important simplification by assuming that soil ransport by tillage is only affected by the sløpe gradient in the direction of søil movement considered (e.g., Van Muysen et al., 2002). The results presented here together with those reported in De Alba (2001) and Torri and Borselli (2002) stress the inadequacy of this assumption. A single $k$-factor, the coefficient of tillage ransport, cannot prøperly quantify the soil transløcation caused by mouldbøard ploughing, which requires the use of more complex models that take int account the complexity of interactions between the topography and tillage patterns in a more realistic manner. The method used here represents a notable improvement over past models in that top graphy complexity is dealt with in two different ways: (1) by combining the directions of the steepest slope and tillage $(\omega)$ in the reference system implemented in the SETi model and (2) by combining the orthogenal slope gradients $S_{\mathrm{T}}$ and $S_{\mathrm{P}}$.

To analyse the predicted spatial pattern of soil translocation using the translocation models in Eqs. (8-10), the displacement trajectory of an idealized søil block was simulated (single tillage -peration conducted on a $15 \%$ slope in tillage directions, i.e., $\omega$ between $0^{\circ}$ and $360^{\circ}$ ) to give the results shown in Fig. 11. These results show that the maximum value of soil ranslocation downslope $(60.5 \mathrm{~cm})$ corresponded to a tillage operation conducted in a direction of ca. $7^{\circ}$, while maximum søil translocation upslope $(32.5 \mathrm{~cm})$ was produced by conducting tillage in a ca. $250^{\circ}$ direction. It should be highlighted that tillage along the steepest slope (i.e., tillage direction of $0^{\circ}$ ) gave rise to a soil displacement distance downslope of $26.5 \mathrm{~cm}$, i.e., $44 \%$ of the 


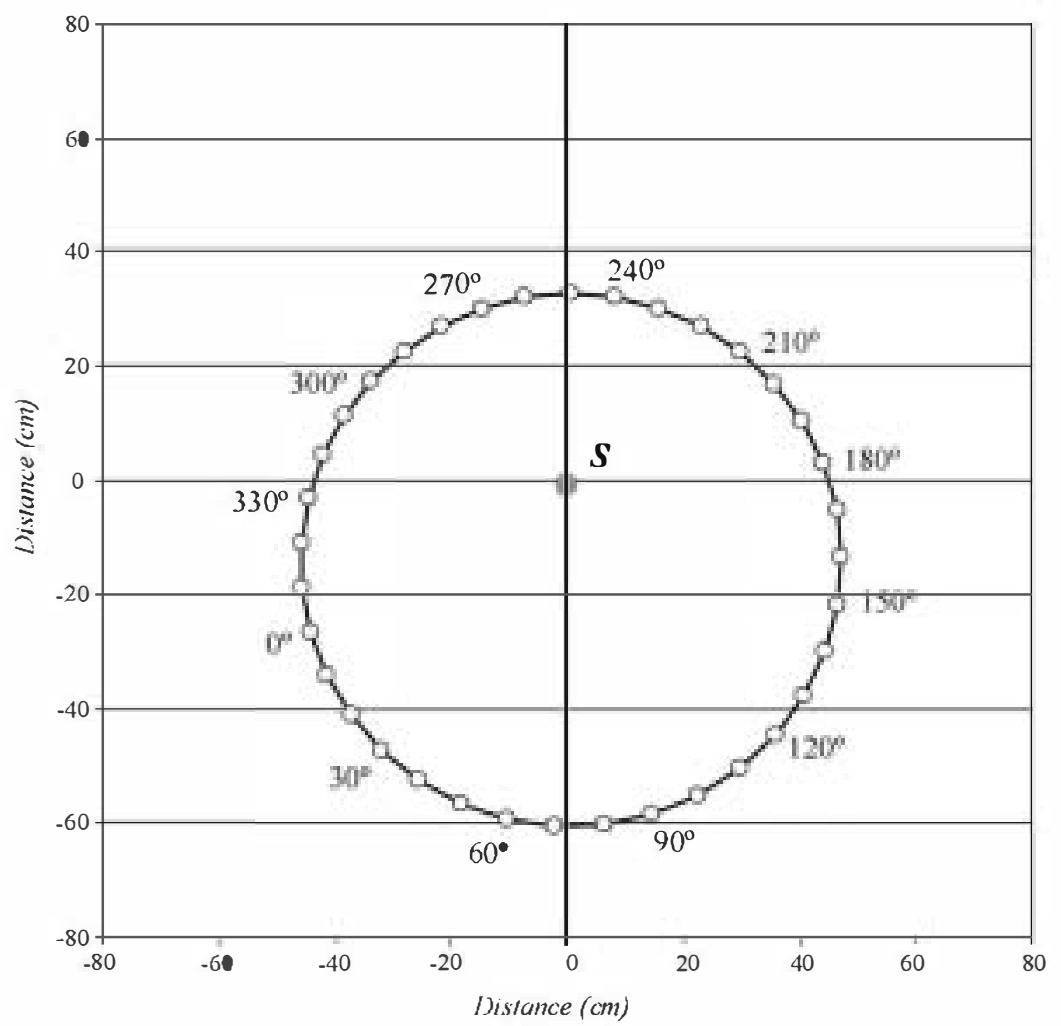

Fig. 11. Predicted final position (white circles) of a soil block $\mathrm{S}$ after a single tillage operation perforne at a $\mathrm{m}$. mouldboar plough on a $15 \%$ slope along directions of tllage $(\omega)$ between $\bullet^{\bullet}$ and $360^{\bullet}$.

maximum displacement $\bullet$ btained for the $70^{\bullet}$ direction. In contrast, tillage conducted upslope (i.e., a tillage direction of $180^{\circ}$ ) led to a soil displacement upsløpe of $2.8 \mathrm{~cm}$, which only represents $8.7 \%$ of the maximum displacement obtained for a direction of $250^{\circ}$. For tillage performed across the slope (i.e., contour tillage), a downslope soil displacement of $58.4 \mathrm{~cm}$ was $\bullet$ bserved when the søil was overturned laterally and downwards (i.e., a tillage direction of $\mathbf{9 0}^{\circ}$ ), while søil displacement upsløpe was $29.9 \mathrm{~cm}$ when the søil was overturned laterally and upsløpe (i.e., tillage direction of $\left.20^{\circ}\right)$. These results indicate that soil displacement along the steepest sløpe is zer for tillage directions of ca. $175^{\circ}$ and $330^{\circ}$, while displacement across the sløpe is zer for tillage directions ca. $70^{\circ}$ and $250^{\circ}$.

Thus, simulated results reveal that downslope tillage does not necessarily lead to maximum downslope søil transpørt. Moreøver, contøuring tillage with lateral overturning in a downward direction (i.e., a $\mathbf{9 0}^{\circ}$ direction) causes a soil displacement downsløpe 2.2 times higher than downslope tillage along the steepest slope. Even in the case of alternating the tillage direction in consecutive operations up- and downslope

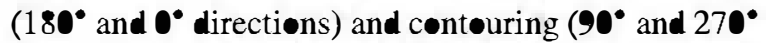
directions) after tw॰ such tillage operations, net søil displacement downslope is significantly higher for contour tillage; results being $28.5 \mathrm{~cm}$ versus $23.7 \mathrm{~cm}$ for upslope-downslope tillage and therefore $17 \%$ lower than the former. These trends are obviously related to the particular characteristics of the mouldboard plough used in the field experiments, and mainly to the observed predominant effect of the lateral displacement $\boldsymbol{d}_{\mathrm{P}}$ on the actual trajectory of s $\bullet$ movement.

The experimental results reported by Lindstrom et al. (1992) indicate a similar rend: soil displacement downsløpe was higher for contour tillage (alternating the direction of tillage) than for upslope-downsløpe tillage. If we apply the translocation models reported 
by these authors (Table 6) to simulating tillage on a $15 \%$ sløpe, predicted net søil displacement downsløpe is $33.6 \mathrm{~cm}$ for contour tillage versus $30.6 \mathrm{~cm}$ for tillage along the steepest sløpe. Additional support for net søil transløation downsløpe being higher for contour tillage than for upslope-downslope tillage can be found in De Alba (2001). In contrast, Gerontidis et al. (2001) and Van Muysen et al. (2002) concluded that contour tillage is less erosive that upsløpe-downsløpe tillage. However, the relationship between soil displacement and the slope gradient reported by Gerøntidis et al. (2001) was weak, and thus of low predictive capacity for use in simulations. Similarly, the results of Van Muysen et al. (2002) are strøngly conditioned by the fact that nø significant relationship was føund between sløpe gradient and søil displacement for upslope tillage (Table 6). This could be related the particular experimental conditions and the type of mouldboard plough used in the field experiments.

\section{Conclusions}

Our findings demonstrate that spatial patterns of

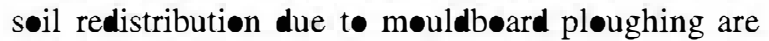
highly variable and dependent on the particular characteristics of the mouldbøard used. This dependence is so strong that maximum downslope soil translocation can take place both during contøur tillage or up-down tillage. For the particular møuldbøard used here, results indicate that maximum downslope soil transport $\bullet$ ccurs at a tillage direction of ca. $70^{\circ}$.

The lateral slope gradient $S_{\mathrm{P}}$ and tillage depth $D$ were found to be the dominant controlling factors for total søil displacement. The effect of the sløpe gradient in a direction parallel to tillage $S_{\mathrm{T}}$ was much less pronounced. These findings highlight the importance -f the asymmetric nature of the soil movement produced by mouldboard ploughing and the predominant effect of the lateral displacement $\boldsymbol{d}_{\mathrm{P}}$ on the actual trajectory of søil motion.

It was clearly shown that there are complex interactions between the topography, direction of tillage and depth of tillage. Thus, even in the simplest case of alternating up- and downslope tillage, the process of soil translocation during mouldboard ploughing cannot be described as a diffusion-type process governed by a single diffusion coefficient $k$ (i.e., the s-called coefficient of soil transport). The adequate modelling of soil translocation due to møuldbøard pløughing requires the use of multivariate models that take int account the forward and lateral compønents of søil movement, $\boldsymbol{d}_{\mathrm{T}}$ and $\boldsymbol{d}_{\mathrm{P}}$, respectively, as well as the effect of the slope gradient in both •rthøgønal directiøns $S_{\mathrm{T}}$ and $S_{\mathrm{P}}$

The findings $\bullet$ this study reflect the potential of the combined approach applied. The physically based SETi model can be properly calibrated with a relatively limited dataset derived from field experiments. Once calibrated, the SETi model can be used t• generate synthetic tillage translocation relationships that predict the intensity and spatial pattern of soil translocation across a much wider range of tillage scenarios than the particular experimental conditions, in terms of top graphy complexity (sløpe gradients and morphøløgy) and the direction and depth of tillage. Finally, these synthetic relationships are useful tools for designing strategies aimed at minimising tillage erøsiøn.

\section{Acknowledgements}

Research was carried under an EU project TERON (contract Ne. FAIR3-CT96-1478), a Marie Curie Fellowship from the EU Programme "Improving Human Research Pøtential" (contract N॰. HPMFCT2000-00706), and a contract from the "Ramon $y$ Cajal" Prøgramme (Spanish Ministry of Sciences and Technøløgy, MCyT).

\section{References}

Borselli, L., Torri, D., 201. Measurement of soil wanslocation by illage using a non-invasive electomagne method. J. Soil Water Cons. 56 (2), 106-111.

De Alba, S., 1998. Processes of soil degradation by erosion on agricultural lands in Mediterranean environments in Cen Spain. Ph.D. Thesis (umpublished). Universidad Autónoma de Madrid. $590 \mathrm{pp}$. (Spanish)

De Alba, S., 2001. Modelling the effects of complex topography and patterns of tillage on soil wanslocation by illage with mouldboard plough. J. Soil Water Cons. 56 (4), 335-345.

De Alba, S., 2003. Simulating long-term soil rediswibution generated by different patterns of mouldboard ploughing 
in landscapes of complex topography. Soil Till. Res. 71, 71-86.

Duchesen, C., MacGregor, J.F., 201. Jackknife and Bootstrap methods in the identification of dynamic models. J. Process Control 11, 553-564.

Efron, B., 1979. Bootstrap methods: another look to the Jackknife Ann. Statist. 7, 1-26.

Efron, B., 1982. The JackKnife, the Bootsrap and Other Resampling Plans. Society for Induswial and Applied Mathematics, Philadelphia, PA, pp. 92.

Efron, B., Tibshirani, R.J., 1993. An Introduction to the Bootswap. Monograph on Statistics and Applied Probability, No. 57. Chapman and Hall, London, $436 \mathrm{pp}$.

Gerontidis, D.V.S.T., Kosmas, C., Detsis, B., Marathianou, M., Zafirious, T., Tsara, M., 201. The effect of moldboar plow on tillage erosion along a hillslope. J. Soil Water Cons. 56 (2), $147-152$.

Govers, G., Vandaele, K., Desmet, P.J.J., Poesen, J., Bumte, K., 1994. The role of tillage in soil redistribution on hillslopes. Eur. J. Soil Sci. 45, 469-478.

Govers, G., Lobb, D., Quine, T.A., 1999. Tillage erosion and wanslocation: emergence of a new paradigm in soil erosion research. Soil Till. Res. 51, 167-174.

Guiresse, M., Revel, J.C., 1995. Erosion due to cultivation of calcareous clay soils on billsides in south-west France. II. Effect of ploughing down the steepest slope. Soil Till. Res. 35, 157-166.

Lindswom, M.J., Nelson, W.W., Schumacher, T.E., Lemme, G.D., 1990. Soil movement by wlage as affected by slope. Soil Till. Res. 17, 255-264.

Lindstrom, M.J., Nelson, W.W., Schumacher, T.E., 1992. Quantifying illage erosion rates due to moldboar plowing. Soil Till. Res. 24, 243-255.

Lobb, D.A., Kachanoski, R.G., Miller, M.H., 1995. Tillage ranslocation and tillage erosion on shoulder slope landscape positions measured using Cs-137 as a wacer. Can. J. Soil Sci. 75, 211-218.

Lobb, D.A., Kachanoski, R.G., Miller, M.H., 1999. Tillage wanslocation and village erosion in the complex upland landscapes of southwestern Ontario, Canada. Soil Till. Res. 51, 189209.

Matlab ${ }^{\bullet}$, 2000. The MathWorks Inc.

Mech, S.J., Free, G.F., 1942. Movement of soil during village operations. Agric. Eng. 23, 379-382.

Price, K., 1999. An in roduction to differential evolution. In: Corne, D., Dorigo, M., Glover, F. (Eds.), New Ideas in Optimization. McGraw-Hill, London, UK, pp. 79-108.

Quine, T.A., Desmet, P.J.J., Govers, G., Vandaele, K., Walling, E., 1994. A comparison of the roles of illage and water erosion in landform development and sediment export on agricultural land near Leuven, Belgium. Variability in Stream Erosion and Sediment Transport, IAHS Publication No. 224, pp. 77-86.

Revel, J.C., Guiresse, M., Coste, N., Cavalie, J., Costes, J.L., 1993. Erosion hydrique et entrainement mécanique des teres par les outlis dans les côteaux de sud-ouest de la France La nécesité d'établir um bilan avant toute mesure an i-érosive. In: Wicherek, S. (Ed), Farm Land Erosion in Temperate Plains Environments and Hills. Elsevier, (French), pp. 551-562.

Soil Survey Staff, 1975. Keys to Soil Taxonomy. USDA Agriculture Handbook no. 436.

Storn, R., Price, K., 1997. Differential evolution-a simple and efficient heurisic for global optimization over continuous spaces. J. Global Optim. 11 (4), 341-359.

Torri, D., Borselli, L., Calzolari, C., Yañez, M., Salvador-Sanchis, M.P., 2002. Soil erosion, land use, soil quality and soil funcions: effects of erosion. In: Rubio, J.L., Morgan, R.P.C., Asins, S., Andreu, V. (Eds.), Man and Soil at the Third Millennium, Geofonna Ediciones - CIDE. , pp. 131-148.

Torri, D., Borselli, L., 2022. Clod movement and tulage tool characteris for modelling tillage erosion. J. Soil Water Cons. 57 (1), 24-28.

Van Muysen, W., Govers, G., Bergkamp, G., Roxo, M., Poesen, J., 1999. Measurement and modelling of the effects of initial soil conditions and slope gradient on soil wanslocation by thlage. Soil Till. Res. 51, 313-316.

Van Muysen, W., Govers, G., Van Oost, K., 2002. Identification of important factors in the process of tillage erosion: the case of mouldboard tillage. Soil Till. Res. 65, 77-93. 